\title{
Late spring ultraviolet levels over the United Kingdom and the link to ozone
}

\author{
J. Austin ${ }^{1}$, C. M. H. Driscoll ${ }^{2}$, S. F. G. Farmer ${ }^{1}$, M. J. Molyneux ${ }^{1}$ \\ ${ }^{1}$ Meteorological Office, London Road, Bracknell, Berkshire, RG12 2SZ, UK \\ ${ }^{2}$ National Radiological Protection Board, Didcot, Chilton, Oxfordshire, OX11 0RQ, UK
}

Received: 25 August 1998 / Revised: 12 January 1999 / Accepted: 25 January 1999

\begin{abstract}
Erythemally-weighted ultraviolet $\left(\mathrm{UV}_{\text {ery }}\right)$ levels measured over southern England, during anticyclonic weather between 30 April and 2 May, 1997, were almost $50 \%$ higher than normally expected for clear skies and were similar to mid-summer values for the first time since measurements began in 1990. Investigation of this episode suggests that a combination of both meteorological and chemical effects were responsible for generating record low ozone amounts for the time of year. Further, comparisons between the A band ultraviolet (315 to $400 \mathrm{~nm}$ wavelength) amounts, and radiative calculations confirm that the high $\mathrm{UV}_{\text {ery }}$ was primarily due to the reduction in total ozone. These results are contrasted with a similar period for 1998, in which near climatological ozone amounts were measured. The prospects for enhanced $\mathrm{UV}_{\text {ery }}$ levels in future years are briefly reviewed in the light of expected increases in stratospheric halogen levels and greenhouse gases.
\end{abstract}

Key words. Atmospheric composition and structure (middle atmosphere - composition and chemistry) . Meterology and atmospheric dynamics (middle atmosphere dynamics; radiative processes)

\section{Introduction}

The possibility of an ozone hole in the Northern Hemisphere has been suggested due to the combination of high chlorine levels and increasing greenhouse gases (GHGs) (Austin et al., 1992). However, it was considered that severe Arctic ozone depletion would not be likely until GHG concentrations increase considerably from their 1980s values and are then able to provide more cooling in the lower stratospheric region to stimulate the occurrence of polar stratospheric clouds
(PSCs). Ozone depletion would then proceed following the reactions of chlorine reservoir species on the surfaces of the clouds (e.g. Solomon, 1990) leading to severe ozone loss as observed in the Antarctic ozone hole (Farman et al., 1985). Further model calculations (Austin and Butchart, 1994) suggested that an Arctic ozone hole might only occur for enhanced GHGs, during cold winters which were dynamically quiescent with no major stratospheric warmings and a delay in the final warming (the seasonal change from winter westerlies to summer easterlies). More recent work using a simplified chemistry-climate model (Shindell et al., 1998) predicted that even the small change in GHGs over the next decade or two will be sufficient to reduce the frequency of stratospheric warmings and trigger enhanced ozone depletion. Indeed, in high latitudes most of the recent winter-spring periods have been colder than the multidecade climatology (SORG, 1993; SORG, 1996; Naujokat and Pawson, 1996; Muller et al., 1996; Rex et al., 1997; Coy et al., 1997; Pawson and Naujokat, 1997). However, there is significant interannual variability in the stratosphere and for example, after a cold start, $1997 / 98$ was relatively mild following a minor stratospheric warming in December-January. During the years in which low temperatures were observed, substantial ozone depletion occurred in high northern latitudes as indicated by model studies (Chipperfield, 1994; Chipperfield et al., 1996) and observations (von der Gathen et al., 1995; Braathen et al., 1998; Rex et al., 1998). While increased GHGs may have contributed to the low temperatures, the additional ozone depletion itself may have led to a reduction in the solar heating in high latitudes (e.g. Shine, 1986; Randel and Wu, 1998; Butchart and Austin, 1996).

In general, in the Arctic incidences of low ozone occur early in the year and, although possibly important for the biosphere, have little consequences for human health as $\mathrm{UV}_{\text {ery }}$ levels do not normally start to become significant in middle and high latitudes until a month or more after the spring equinox (UMIRG, 1996, Fig. 2.4). For example, during 1996 record low ozone levels were 
observed over Camborne $\left(50.2^{\circ} \mathrm{N}, 5.3^{\circ} \mathrm{W}\right)$ in the United Kingdom in early March (Driscoll, 1996) and this gave rise to peak $\mathrm{UV}_{\text {ery }}$ of $63 \mathrm{mWm}^{-2}$, some $50 \%$ higher than normal despite partially cloudy skies. For the amount of ozone present, calculations give a peak clear sky $\mathrm{UV}_{\text {ery }}$ of $82 \mathrm{mWm}^{-2}$ but this is somewhat lower than noon clear sky summer values of about $160 \mathrm{mWm}^{-2}$. During 1997, however, the low spring temperatures in the stratosphere combined with a delay in the final warming have provided the conditions for $\mathrm{UV}_{\text {ery }}$ levels to be similar to summer values almost two months early. Here we analyse data during the period 30 April to 2 May, 1997, to determine the causes of the high $\mathrm{UV}_{\text {ery }}$ episode and contrast the period with early May 1998 when near normal $\mathrm{UV}_{e r y}$ occurred also in anticyclonic conditions.

\section{Broad-band ultraviolet data}

In 1988, the National Radiological Protection Board (NRPB) set up three monitoring stations to make measurements at Chilton $\left(51.6^{\circ} \mathrm{N}\right)$, Leeds $\left(53.8^{\circ} \mathrm{N}\right)$ and Glasgow $\left(55.9^{\circ} \mathrm{N}\right)$. To these sites, Camborne $\left(50.2^{\circ} \mathrm{N}\right)$ and Lerwick $\left(60.1^{\circ} \mathrm{N}\right)$ were added in 1993 and Kinloss $\left(57.6^{\circ} \mathrm{N}\right)$ was added in 1996: see Fig. 1. Measurements of visible (approximate wavelength range $400-770 \mathrm{~nm}$ ), ultraviolet A ( $315-400 \mathrm{~nm}$, UVA) and ultraviolet radi-

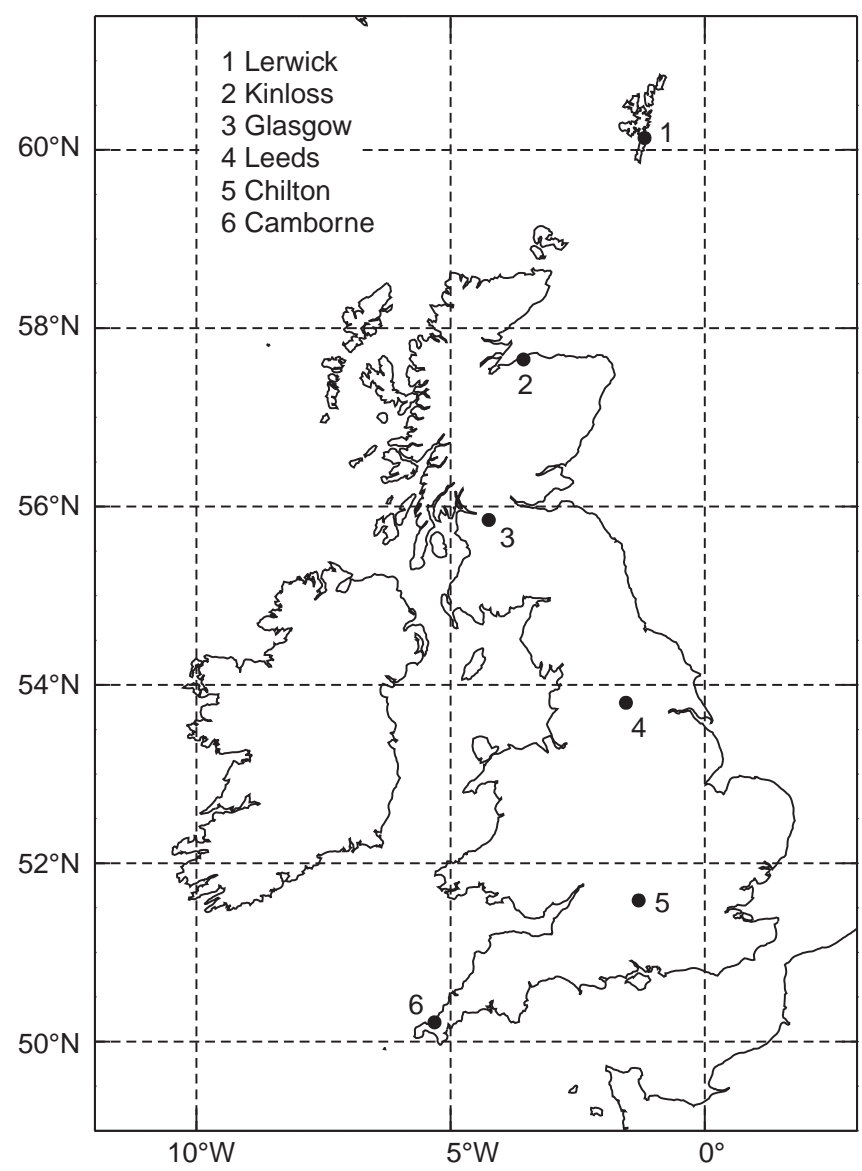

Fig. 1. Map of the UK and Ireland showing the positions of the $6 \mathrm{UV}$ monitoring stations. In addition ozone measurements are made at Camborne (station 6) and Lerwick (station 1) ation weighted by the erythemal action spectrum (McKinlay and Diffey, 1987; 290-400 nm, $\mathrm{UV}_{\text {ery }}$ ) have been made simultaneously and continuously using a system based on three commercially available broad-band detectors. The measurements are designed to provide information regarding the range of variation of solar UV at different latitudes in the UK with the time of year and from year to year, and to establish baseline UV.

The erythemally-weighted UV detector is a modification of the 500 series detector produced by the Solar Light Company and incorporates a quartz hemispherical dome. Solar radiation incident upon the dome passes through a pre-filter, which absorbs visible and infrared radiation. The solar UV is then wavelengthshifted by a magnesium tungstate phosphor deposited on a green filter. This filter absorbs residual UV and the small amount of red light transmitted by the pre-filter. The emission from the fluorescing phosphor is centred at $500 \mathrm{~nm}$ and is detected by a vacuum photodiode. The UVA detector (Model SD104A-Cos) consists of a polytetrafluoroethylene cosine diffuser, A UVA transmission filter and a large area gallium arsenide phosphide photovoltaic diode. The peak response is at $367 \mathrm{~nm}$ with a bandwidth (full width, half maximum) of $38 \mathrm{~nm}$. The third detector (Model SD104L-Cos) measures the photopic illuminance (lux) in the visible part of the solar spectrum. It consists of a white acrylic cosine diffuser, a transmission filter and a large area silicon photodiode. This detector has a spectral response which approximates to the photopic curve of the International Commission on Illumination (CIE). The detectors are calibrated using standard sources traceable to national standards laboratories. In addition, all detectors are calibrated against the Sun at various times at and around noon on a clear summer's day. This is done with the aid of a scanning spectroradiometer, calibrated against lamps traceable to national standards. The detectors are linked, with in-house designed preamplifiers and an analogue-to-digital converter, to microcomputers for data acquisition and analysis. Data are recorded every $20 \mathrm{~s}$ to give mean irradiance levels over 5 min periods throughout a $24 \mathrm{~h}$ cycle. At the $95 \%$ confidence level, measurement uncertainties are estimated to be no greater than $15 \%$ for the two UV detectors, taking account of all potential instrument and calibration uncertainties. Instrument uncertainties are estimated to be lower than this in the region of 5 to $10 \%$.

Sufficient data now exist for an approximate climatology to be constructed for Chilton which is presented in Sect. 2.1. We also present provisional data for Glasgow. In Sects. 2.2 and 2.3 we discuss two case studies for Southern England. Since the connection with total ozone is an important one, the data at Camborne where ozone measurements are also available, are investigated.

\subsection{UV climatologies for clear skies for Chilton $\left(51.6^{\circ} \mathrm{N}\right)$ and Glasgow $\left(55.9^{\circ} \mathrm{N}\right)$}

Only those days which could be identified by their smooth diurnal variation as clear skies or near clear skies 
are considered, because of the complications associated with the interpretation of $\mathrm{UV}_{\text {ery }}$ on cloudy days. However, for the period $24 / 4 / 1990-31 / 5 / 1998$ only 297 clear days have occurred at Chilton spread over only 220 days of the year. Thus nearly $40 \%$ of the days have not had a completely clear sky in any year since 1990. At Glasgow for the years 1992-1997 only 49 days had completely clear skies. The year was divided into 26 periods of 2 weeks, thus averaging about 11 data points for Chilton in each 2-week period, and the mean and standard deviation was computed for each period (see Table 1).

Peak $U_{\text {ery }}$ values for the clear-sky days (Fig. 2a) show some day-to-day variability due to ozone and, presumably, aerosol changes, rather than random error in the data, which is of order $0.5 \%$. Also, there is no evidence of instrument drift during the period. At Chilton, for the 14 day mean centred on 1 May, measured $\mathrm{UV}_{\text {ery }}=103.6 \pm 5.5 \mathrm{mWm}^{-2}$ and for the period centred on 27 June $\mathrm{UV}_{\text {ery }}=157.4 \pm 2.4 \mathrm{mWm}^{-2}$, where the error bars denote the standard error of the mean, and exclude instrument systematic error. At Glasgow $\mathrm{UV}_{\text {ery }}$ values were $6 \%$ and $11 \%$ lower for the late spring and summer periods respectively, but are considerably lower than at Chilton during winter. This is to be expected given the more northerly location of Glasgow, although there were rather fewer clear skies, making comparisons difficult.

\subsection{Case study, 1997}

On 1 and 2 May, 1997, the Chilton $\mathrm{UV}_{\text {ery }}$ values of 149 and $148 \mathrm{mWm}^{-2}$, exceeded the derived climatology by
$43 \%$, equal to $95 \%$ of the normal peak summer value. Apart from 1997, the largest $\mathrm{UV}_{\text {ery }}$ values attained during the period 23 April to 6 May were $122 \mathrm{mWm}^{-2}$, observed in 1995.

Figure $2 \mathrm{~b}$ shows $\mathrm{UV}_{\text {ery }}$ data at Camborne for 30 April 1997 to 2 May 1997 Additional reflection from the small amount of cloud that was present could have occurred on 30 April 1997. Also, total ozone was lower on 30 April 97 than on the following two days which would have contributed an extra $2 \%$ in $\mathrm{UV}_{\text {ery }}$. On this day $\mathrm{UV}_{\text {ery }}$ peaked at $163.3 \pm 0.6 \mathrm{mWm}^{-2}$, which just exceeds the peak summer value expected (the Chilton 27 June climatology, corrected for the $1^{\circ}$ latitude difference between Camborne and Chilton).

\subsection{Case study, 1998}

In contrast to the 1997 case study, during 1998 the maximum $\mathrm{UV}_{\text {ery }}$ observed for the early May period was only $97 \mathrm{mWm}^{-2}$ on 2 May 1998 at Chilton during partially cloudy skies, and $106 \mathrm{mWm}^{-2}$ at Camborne on 3 May 1998. Figure 2c shows the data at Camborne for the period 2-3 May 1998. On 3 May 1998, the best example of a clear sky day during the period, the peak UV was $106.4 \pm 0.2 \mathrm{mWm}^{-2}$, in agreement with the climatology for Chilton when allowance is made for the slight latitude difference.

Figure $2 \mathrm{~d}$ shows the UVA values at Camborne for sample days during the two periods in 1997 and 1998. Despite the fact that peak $\mathrm{UV}_{\text {ery }}$ was some $50 \%$ higher in 1997 than in 1998, the peak UVA values differed by only about $10 \%$. This implies that the major change
Table 1. Noon clear sky $\mathrm{UV}_{\text {ery }}$ climatologies for Chilton, 19901997 and Glasgow, 1992-1997. The error bars denote the expected errors in the mean which for small numbers of points are not necessarily good estimates of the true uncertainty. The values for Glasgow are based on few data points and should be treated with caution

\begin{tabular}{|c|c|c|c|c|}
\hline Period & $\begin{array}{l}\text { Mean Chilton } \\
\left(\mathrm{mWm}^{-2}\right)\end{array}$ & $\begin{array}{l}\text { Number of } \\
\text { points }\end{array}$ & Mean Glasgow & $\begin{array}{l}\text { Number of } \\
\text { points }\end{array}$ \\
\hline 1-14 Jan. & $6.3 \pm 0.4$ & 14 & $4.5 \pm 1.1$ & 3 \\
\hline 15-28 Jan. & $8.4 \pm 0.6$ & 11 & $5.0 \pm 0.1$ & 2 \\
\hline 29 Jan.-11 Feb. & $12.1 \pm 0.4$ & 10 & $6.7 \pm 1.6$ & 3 \\
\hline 12-25 Feb. & $22.2 \pm 1.8$ & 13 & No data & 0 \\
\hline 26 Feb.-11 Mar. & $38.9 \pm 2.6$ & 11 & No data & 0 \\
\hline 12-25 Mar. & $51.2 \pm 2.3$ & 13 & $49.0 \pm-$ & 1 \\
\hline 26 Mar.-8 Apr. & $66.5 \pm 4.2$ & 12 & $57.9 \pm-$ & 1 \\
\hline 9-22 Apr. & $76.3 \pm 6.8$ & 8 & $70.6 \pm 0.3$ & 2 \\
\hline 23 Apr.-6 May & $103.6 \pm 5.5$ & 20 & $97.6 \pm 3.6$ & 2 \\
\hline 7-20 May & $122.8 \pm 4.0$ & 12 & $96.0 \pm 2.3$ & 6 \\
\hline 21 May-3 June & $131.9 \pm 4.4$ & 13 & $109.1 \pm 27.4$ & 2 \\
\hline 4-17 June & $151.0 \pm 3.1$ & 10 & $141.4 \pm 13.1$ & 2 \\
\hline 18 June-1 July & $157.4 \pm 2.4$ & 9 & $139.7 \pm 4.0$ & 4 \\
\hline 2-15 July & $147.6 \pm 4.5$ & 11 & $126.1 \pm-$ & 1 \\
\hline 16-29 July & $140.5 \pm 4.3$ & 15 & No data & 0 \\
\hline 30 July-12 Aug. & $126.8 \pm 3.0$ & 12 & $107.3 \pm 17.8$ & 2 \\
\hline 13-26 Aug. & $122.7 \pm 5.0$ & 10 & No data & 0 \\
\hline 27 Aug.-9 Sep. & $93.7 \pm 4.4$ & 9 & $105.1 \pm-$ & 1 \\
\hline 10-23 Sep. & $73.6 \pm 2.4$ & 8 & $63.8 \pm-$ & 1 \\
\hline 24 Sep.-7 Oct. & $68.0 \pm-$ & 1 & No data & 0 \\
\hline $8-21$ Oct. & $38.9 \pm 2.2$ & 14 & $22.3 \pm 2.1$ & 4 \\
\hline 22 Oct. -4 Nov. & $22.2 \pm 1.5$ & 12 & $15.8 \pm-$ & 1 \\
\hline 5-18 Nov. & $12.3 \pm 0.8$ & 13 & $6.5 \pm 0.9$ & 4 \\
\hline 19 Nov.-1 Dec & $9.2 \pm 1.0$ & 6 & $6.6 \pm 0.9$ & 2 \\
\hline 2 Dec. -15 Dec & $6.2 \pm 0.3$ & 17 & $3.0 \pm-$ & 1 \\
\hline 16-31 Dec. & $4.7 \pm 0.4$ & 13 & $2.5 \pm 0.3$ & 4 \\
\hline
\end{tabular}



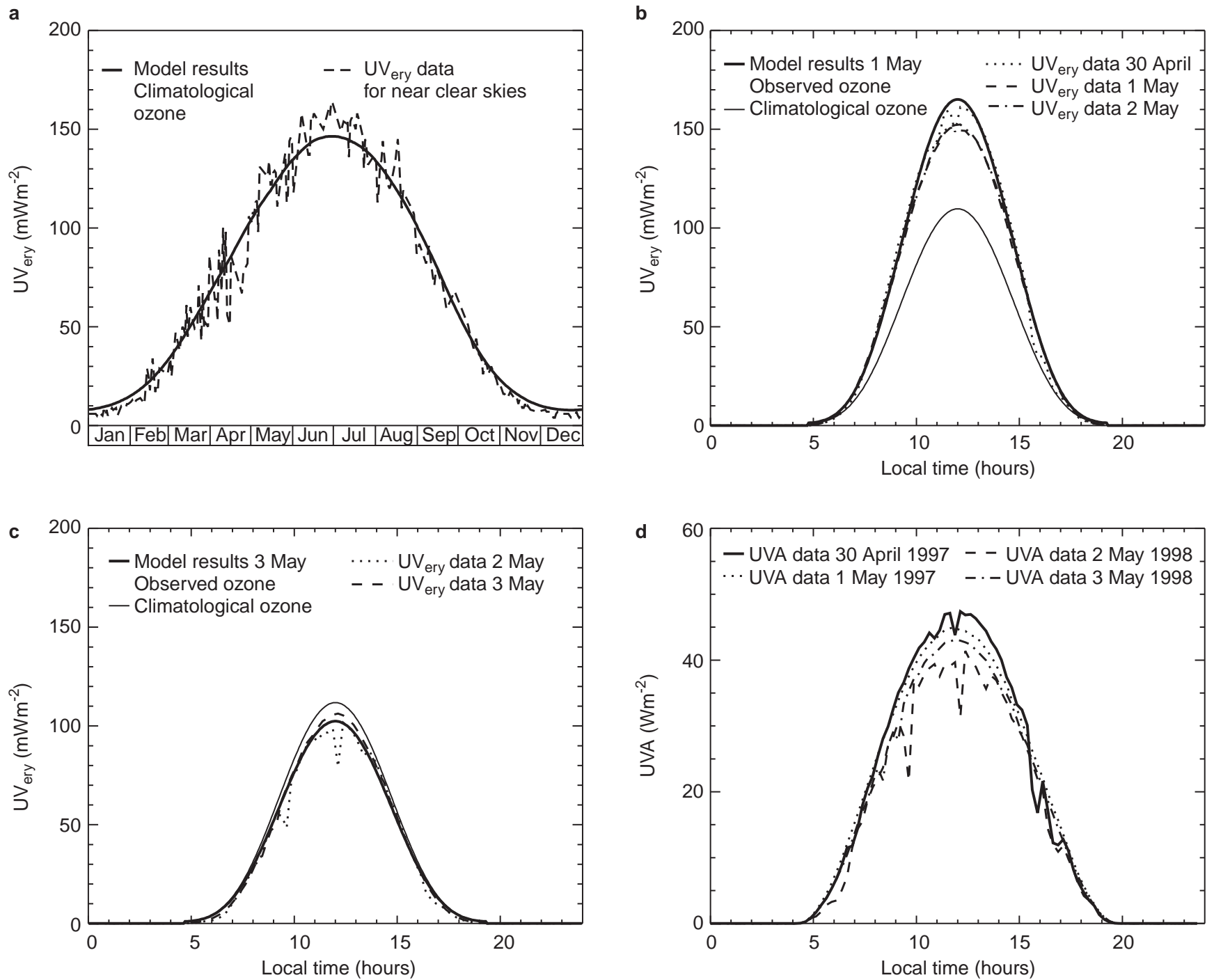

Fig. 2a. Observed peak daily values of $\mathrm{UV}_{\text {ery }}$ for $24 / 4 / 1990-31 / 5 / 1998$ at Chilton, Oxfordshire $\left(51.6^{\circ} \mathrm{N}, 1.3^{\circ} \mathrm{W}\right)$ (broken line), together with calculated noon values for clear skies (solid line). $\mathbf{b} \mathrm{UV}_{\text {ery }}$ data at Camborne $\left(50.2^{\circ} \mathrm{N}, 5.3^{\circ} \mathrm{W}\right)$ for $30 / 4 / 97$ to $2 / 5 / 97$ (broken lines) together with calculated values for 1 May (solid lines). Upper solid curve: calculated values assuming the observed total ozone value of 271 DU measured at Camborne. Lower solid curve: calculated values

occurred for wavelengths less than $315 \mathrm{~nm}$, which are significantly affected by ozone.

\section{Measurements of ozone}

The United Kingdom Meteorological Office measures total ozone daily, when conditions allow, at Camborne in Cornwall and Lerwick $\left(60.1^{\circ} \mathrm{N}, 1.2^{\circ} \mathrm{W}\right)$ in the Shetland Islands, using manually operated Dobson spectrophotometers (WMO, 1996). These instruments are regularly calibrated at international intercomparisons, and the Camborne instrument was last calibrated in 1995. Monthly checks on the instruments are also carried out using a mercury lamp for wavelength accuracy and a standard lamp for calibration accuracy.

assuming climatological total ozone (373 DU). c UV $\mathrm{Ury}_{\text {ry }}$ data at Camborne on 2/5/1998 and 3/5/1998 (broken lines) together with calculated values for 3/5/1998 (solid lines). Upper solid curve: calculated values assuming the climatological total ozone (373 DU). Lower solid curve: calculated values assuming the total ozone value of 400 DU measured at Camborne. d UVA data at Camborne on 30/4/ 1997, 1/5/1997, 2/5/1998 and 3/5/1998

The carefully scrutinised data series begin in 1979 for Southern England and 1981 for Lerwick. Several observations are made at different solar elevations each day and only the most reliable measurements are used to derive the average value of total ozone for a given day. Total ozone data are also available in near real-time from a Total Ozone Mapping Spectrometer (TOMS see Stolarski, 1993 for a general description of the instrument) on the Earth Probe satellite, at the positions of Camborne and Lerwick. Comparisons have also been made between the Lerwick instrument and a similar instrument operating at Oslo $\left(59.9^{\circ} \mathrm{N}, 10.7^{\circ} \mathrm{E}\right)$, which revealed a mean difference of less than $1 \%$ during the 13 month period September 1995-September 1996, providing additional confidence in the accuracy of the measurements. 
The ozone profile is measured at Lerwick using a Science Pump Corporation electrochemical cell ECC5 which is interfaced to a standard radiosonde package carried by a meteorological balloon. Ambient air is pumped through potassium iodide solution in the cell and the resulting current is proportional to the number of ozone molecules in the sample. Profiles are obtained at least three times per week in winter and early spring but less often during the rest of the year. In April, regular ascents began in 1992 (WMO, 1996).

\subsection{Observations for the 1996/97 period}

For much of the winter 1996-97, daily values of total ozone were within two standard deviations of the climatological mean at both Camborne (Fig. 3a) and Lerwick, but with the March and April monthly means below normal by $11-16 \%$. Values show considerable day-to-day variability especially in the winter and spring, due primarily to meteorological effects including movements in the polar vortex but superimposed on this day-to-day variation is slow chemical change (Chipperfield, 1994; Chipperfield et al., 1996; von der Gaathen et al., 1995; Braathen et al., 1997; Rex et al., 1998). Between 29 April and 2 May, 1997, very low daily values for the time of year were recorded. This included the lowest measurements ever made by the Camborne/ Bracknell Dobson instrument for April and May (266 and 271 DU respectively). Although even lower values have been recorded in March at these stations (206 and 195 DU at Camborne and Lerwick respectively in March 1996), the fact that very low values occurred so late in the year is significant for $\mathrm{UV}_{\text {ery }}$ levels as indicated in Fig. 2. During the period when data have been taken in Southern England, there has been a general tendency for the April minima to become lower at a rate similar to the overall downward trend of about 2 DU per year.

An ozone ascent was made at Lerwick on 30 April, but because of an electronics fault, data were only available up to $18 \mathrm{~km}$ rather than the typical limit of about $30 \mathrm{~km}$. Compared with the April mean (Fig. 3b), on 30 April there was approximately 50 DU less ozone in the 10 to $18 \mathrm{~km}$ range. On 30 April total ozone was also measured from the Dobson spectrophotometer at Lerwick and was found to be 295 DU, approximately 80 DU below the mean for April for the period over which measurements have been made. This, together with the profile information from the ozonesonde, indicates that the ozone above $18 \mathrm{~km}$ was about 30 DU below the monthly mean.

For April and May 1997 the mean and random error for the difference Dobson-TOMS were typically of the order of $1 \%$ and $3 \%$. During the period 30 April-2 May 1997 the largest difference was $-3 \%$ at Camborne and $+4 \%$ at Lerwick. The TOMS data for 30 April, showed a region of high ozone in the high-latitude western hemisphere, where the total column approached 500 DU, but much of the high-latitude eastern hemisphere was considerably lower at about 300 DU. In particular, there was a small region over central and northern England with ozone values approaching values normally only seen in the tropics at this time of year. Total ozone measured at Copenhagen $\left(55.7^{\circ} \mathrm{N}, 12.6^{\circ} \mathrm{E}\right)$ was also very low on 1 May, 1997, (279 DU), almost 3 standard deviations below the long term mean.
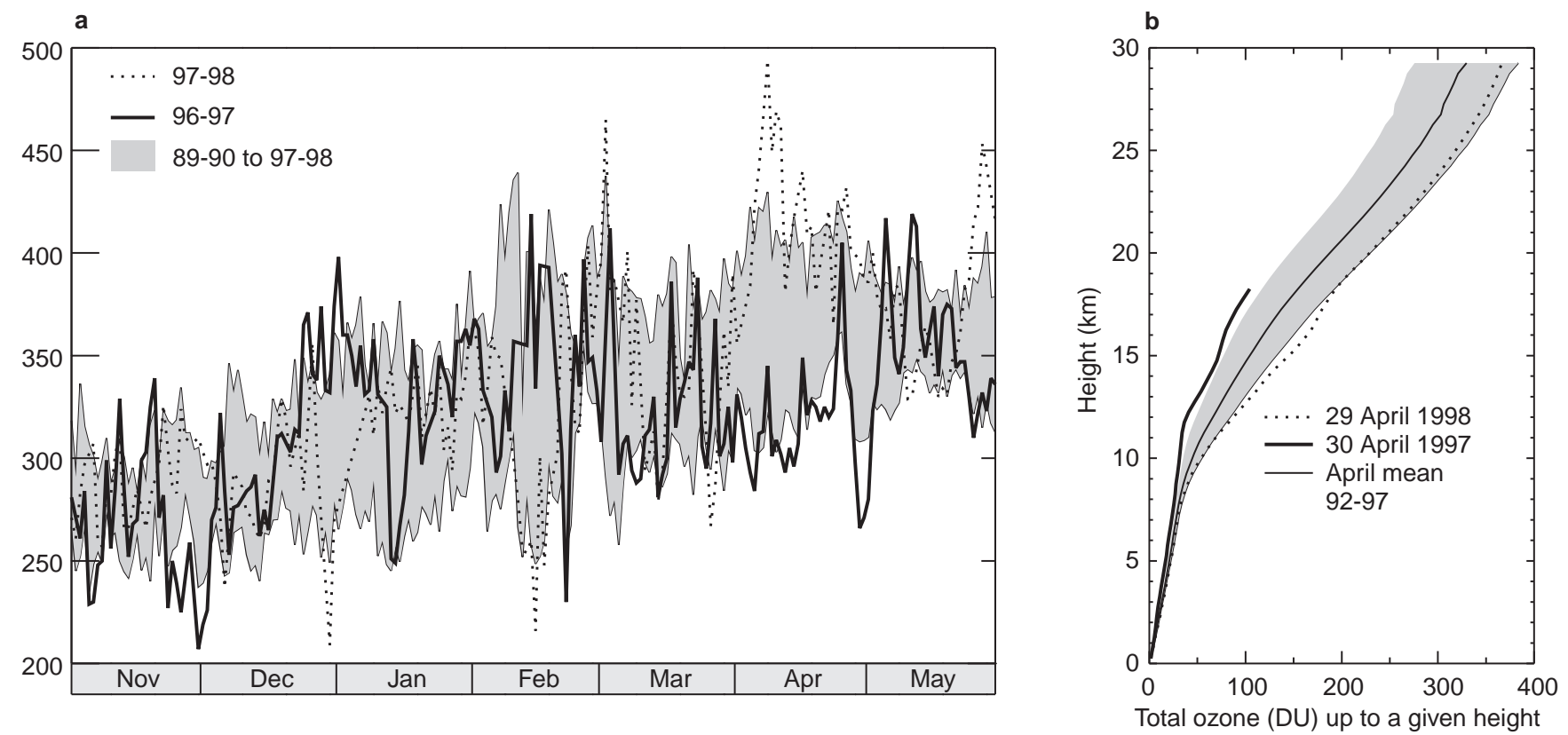

Fig. 3a. Total ozone measurements at Camborne for the winters 1996-97 (solid line) and 1997-98 (broken line). The shaded region shows the mean \pm 1 standard deviation of the daily values for each day for the period 1989-98. b Total ozone at Lerwick from the surface to a given height as a function of height. Thick solid line: observations for 30 April 1997; thick broken line: observations for 29 April 1998; thin solid line: mean values for April observations; shaded region: mean \pm 1 standard deviation. The mean and standard deviations were calculated from the 28 individual profiles measured in April between 1992 and 1997, but excluding the profile measured on 30 April 1997 


\subsection{Observations for the $1997 / 98$ period}

Also included in Fig. 3 are the results for the 1997/98 winter and spring. During the early part of the winter there were two periods, during December and February when total ozone at Camborne was low, but otherwise values were near normal. During the period when UV levels increase rapidly, in April and May, total ozone was generally much higher than in the corresponding period in 1997. The vertical profiles at Lerwick confirm this general picture and in particular, for 29 April, 1998, ozone was generally one standard deviation above the mean. This compares with the profile one year earlier which was more than one standard deviation below the mean over almost the entire measured range.

The TOMS data for 2 May, 1998 contrasts markedly with the data for the 1997 period. In 1998, ozone amounts were much closer to the long-term climatology with large areas in high latitudes approaching or exceeding 500 DU. Over the UK and Europe values were quite close to the long-term climatology and some 100 DU higher than in 1997.

\section{Modelling UV $\mathbf{V}_{\text {ery }}$}

To model $\mathrm{UV}_{\text {ery }}$ for the periods of interest, the radiative transfer scheme used to compute photolysis rates in the Meteorological Office photochemical model (Butchart and Austin, 1996) has been extended to the ground and the downward component of the UV irradiance was weighted to the McKinlay-Diffey action spectrum for erythema (McKinlay and Diffey, 1987). The calculations used the ozone climatology for Camborne/Bracknell for the period 1979-1996 and the total aerosol optical depth was assumed to be 0.2 in the UV part of the spectrum. The model results (smooth curve in Fig. 2a) show generally good agreement, perhaps overpredicting $\mathrm{UV}_{e r y}$ in the winter months and underpredicting in the summer months. However, the results are slightly dependent on the amount of aerosol assumed and seasonal variations have not been taken into consideration. Also, identifying truly clear skies in the winter months is quite difficult due to the small UV signal while the large winter solar zenith angles could have resulted in a small instrument bias. Regarding the values in the summer months, these were calculated using an ozone climatology valid for all meteorological conditions and it is quite likely that the observed ozone would actually have been slightly lower during the anticyclonic conditions to which the $\mathrm{UV}_{\text {ery }}$ values refer. Comparing the results in more detail, at Chilton, the model predicted values are $104.4 \mathrm{mWm}^{-2}$ and $146.4 \mathrm{mWm}^{-2}$ on 30 April and 27 June respectively. The differences from the climatology (Table 1) of $1 \%$ and $7 \%$ respectively are well within the combined systematic errors of the instrument (about 10-15\%) and the ozone cross-section data (about $20 \%$, for a $95 \%$ confidence level, DeMore et al., 1997) used in the model calculations. This suggests incidentally that the true systematic errors in the measurements and cross-section data may be somewhat smaller than the theoretical values.

The model $\mathrm{UV}_{\text {ery }}$ results for Camborne for the periods 30 April to 2 May, 1997, is shown in Fig. 2b. The lower solid curve is the model calculation assuming climatological ozone values, and the upper solid curve assumes the observed ozone for 1 May, 1997 (271 DU). For the observed ozone, the model overestimated the peak by $9 \%$ (165.1 compared to an observed $151.4 \pm$ $0.7 \mathrm{mWm}^{-2}$ on 1 May where the error bar denotes the random error in the measurement) but the diurnal variation of the $\mathrm{UV}_{\text {ery }}$ observations is very well reproduced. There is a substantial difference between the calculated $\mathrm{UV}_{\text {ery }}$ results for the two ozone values demonstrating that the increased observed $\mathrm{UV}_{\text {ery }}$ in early May, 1997, was almost entirely due to ozone change. This supports the conclusion obtained in Sect. 2, on the basis of the UVA measurements.

For 2 and 3 May, 1998, observed peak $\mathrm{UV}_{\text {ery }}$ values at Camborne were $101.7 \pm 2.1$ and $106.4 \pm 0.2 \mathrm{mWm}^{-2}$ and again this compares very favourably with the calculated value of $102.4 \mathrm{mWm}^{-2}$ for 3 May 1998 assuming the measured total ozone of 400 DU (lower solid curve in Fig. 2c). With climatological ozone (373 DU, upper solid curve in Fig. 2c) the calculated peak $\mathrm{UV}_{\text {ery }}$ was $111.8 \mathrm{mWm}^{-2}$. These values are all within one standard deviation of the expected $\mathrm{UV}_{\text {ery }}$ values for Camborne (the Chilton climatology, Table 1, corrected for the latitudinal difference between Camborne and Chilton).

\section{Analysis of results}

\subsection{Meteorological conditions}

In this section, the temperature conditions in the lower stratosphere during the winter and spring periods are summarised with an emphasis on the likelihood of ozone destruction on the surfaces of PSCs. A commonly used diagnostic is the minimum temperature for the region north of $45^{\circ} \mathrm{N}$, shown in Fig. 4 from UK Meteorological Office stratospheric analyses (Swinbank and O'Neill, 1994). The shaded region shows the range of minimum values for each day for the periods 1 November 1991-31 May 1992 to 1 November 1995-31 May 1996. The values for the period 1 November 1996-31 May 1997 and 1 November 1997-31 May 1998 are indicated by the solid and dotted lines respectively. For comparison the thermodynamic equilibrium temperatures (Hanson and Mauersberger, 1988) for the formation of nitric acid trihydrate (NAT) and pure ice (ICE) PSCs are indicated by the broken lines parallel to the abscissa, assuming 10 ppbv $\mathrm{HNO}_{3}$ and 5 ppmv $\mathrm{H}_{2} \mathrm{O}$. Although the early part of the 1996/97 winter was relatively mild, temperatures below the NAT threshold were observed well into March, a period when chemical ozone destruction would have been quite marked. In contrast, the 1997/98 winter was very cold early on, with ice temperatures occurring in December but the stratospheric warming in January increased temperatures 


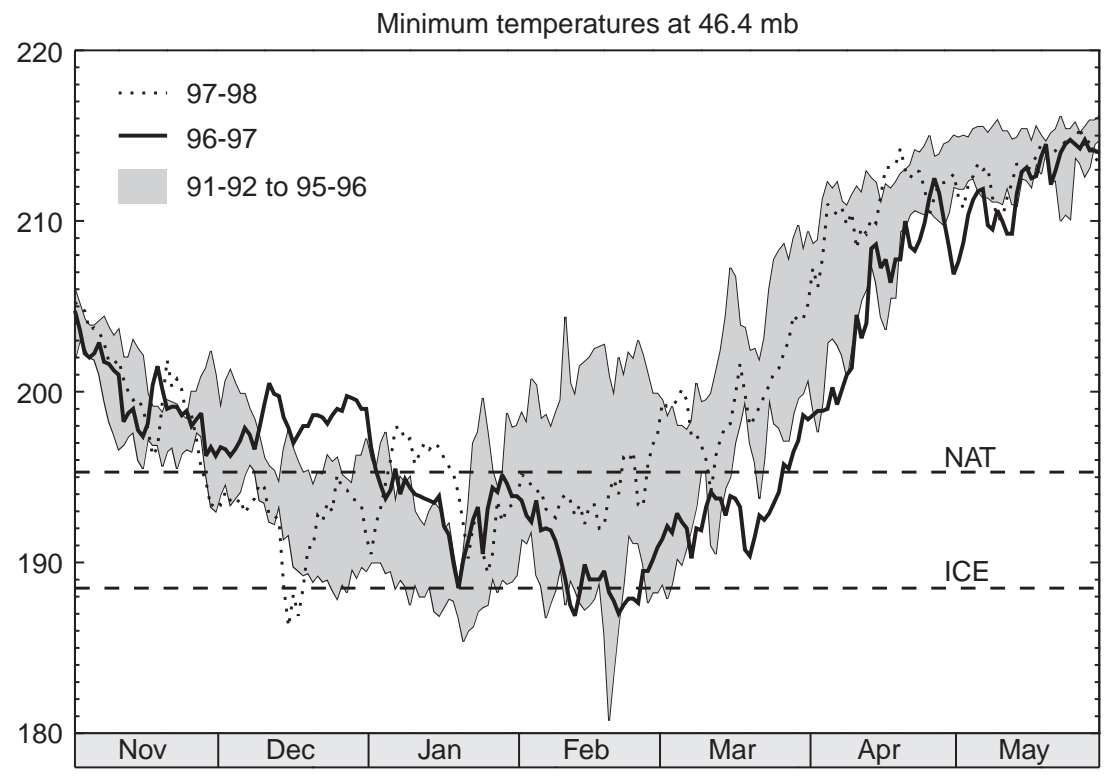

Fig. 4. Minimum temperatures for the region north of $45^{\circ} \mathrm{N}$ from UK Meteorological Office stratospheric analyses. The shaded region shows the range of minimum values for each day for the periods $1 / 11 / 1991-31 / 5 / 1992$ to $1 / 11 / 1995-31 / 5 /$ 1996. The values for the period $1 / 11 / 1996-31 / 5 /$ 1997 and 1/11/1997-31/5/1998 are indicated by the solid and dashed lines. For comparison the thermodynamic equilibrium temperatures for the formation of nitric acid trihydrate $(N A T)$ and pure ice (ICE) PSCs are indicated by the broken lines parallel to the abscissa significantly. Following the warming further cooling resulted, but temperatures were only just low enough to support PSCs for a short period during the remainder of the winter, in contrast with 1996/97.

\subsection{Air parcel behaviour}

To determine the likely origin of the air arriving in the lower stratosphere across the UK, we computed, using the UKMO stratospheric analyses (Swinbank and O'Neill, 1994), a range of back trajectories arriving at locations spread evenly between the positions $50-60^{\circ} \mathrm{N}$ and $10^{\circ} \mathrm{W}-10^{\circ} \mathrm{E}$ on 30 April 1997 and 3 May 1998. The trajectories were assumed to be isentropic, a good approximation for actual air motions (Austin and Tuck, 1985; Knudsen and Carver, 1994) and were calculated for the potential temperature surfaces $400 \mathrm{~K}, 475 \mathrm{~K}$, $550 \mathrm{~K}$ and $625 \mathrm{~K}$ (approximate altitudes 18, 20, 22 and $24 \mathrm{~km}$ respectively). At each level, adjacent air parcels (Figs. 5 and 6) show similar behaviour providing confidence in the computed trajectories (Austin and Tuck, 1985).

For 1997 , on the $550 \mathrm{~K}$ and $625 \mathrm{~K}$ surfaces, all the air parcels travelled around the polar vortex, which was somewhat elongated in shape. Comparison with the TOMS map for 30 April shows that the the air parcels at these levels were approximately confined to the region where total ozone was low. Perusal of the potential vorticity charts for this period (see Clough et al., 1985 and Hoskins et al., 1985, for the significance of this quantity), indicated that the UK was at the edge of the polar vortex, which extended into the eastern hemisphere, broadly similar in position to that of the trajectories. On the $400 \mathrm{~K}$ surface, all the air parcels had their origin in subtropical latitudes. The results at $475 \mathrm{~K}$ showed a combination of both flow regimes, with the south-west parcels transported from the subtropics and the remainder from the edge of the polar vortex.
The trajectories ending on 2 May, 1998, (Fig. 5) show distinctly different behaviour than for 1997. At each level the trajectories are again broadly consistent and although the majority of parcels had their origin in low latitudes at the upper levels, at $400 \mathrm{~K}$ most parcels started in middle latitudes. Also there was no clearly defined region (e.g. the vortex) around which the air parcels travelled.

\section{Discussion}

\subsection{Meteorological and chemical effects on ozone}

For some decades it has been recognised that total ozone is correlated with meteorological parameters (e.g. Ohring and Muench, 1960). On this basis, Steinbrecht et al. (1998) have deduced that the measured change in tropopause height over the last $30 \mathrm{y}$ has resulted in about 10 DU total ozone loss. Our own data at Camborne and Lerwick have also shown a clear anticorrelation between total ozone and the height of the tropopause over many years (Molyneux et al., 1998). On 30 April, 1997, when anticyclonic conditions were present in the troposphere, the height of the transition, between low ozone tropospheric air and higher ozone stratospheric air, was raised by about $3 \mathrm{~km}$. Also, on the $400 \mathrm{~K}$ potential temperature surface, the air parcels had been transported from the sub-tropics where ozone concentrations are generally low (Russell et al., 1986). Together, these two effects gave rise to low total ozone below $18 \mathrm{~km}$ due to meteorological processes. Further, although 1997 was warmer than normal early in the winter, PSCs could nonetheless form from the beginning of January until 26 March (Fig. 4), when exceptionally cold conditions prevailed, allowing the possibility of ozone destruction in the polar vortex later into the spring than in previous years (Chipperfield, 1994; Chipperfield et al., 1996; von der Gathen et al., 1995; Braathen et al., 1997; Rex et al., 1998). Consequently 

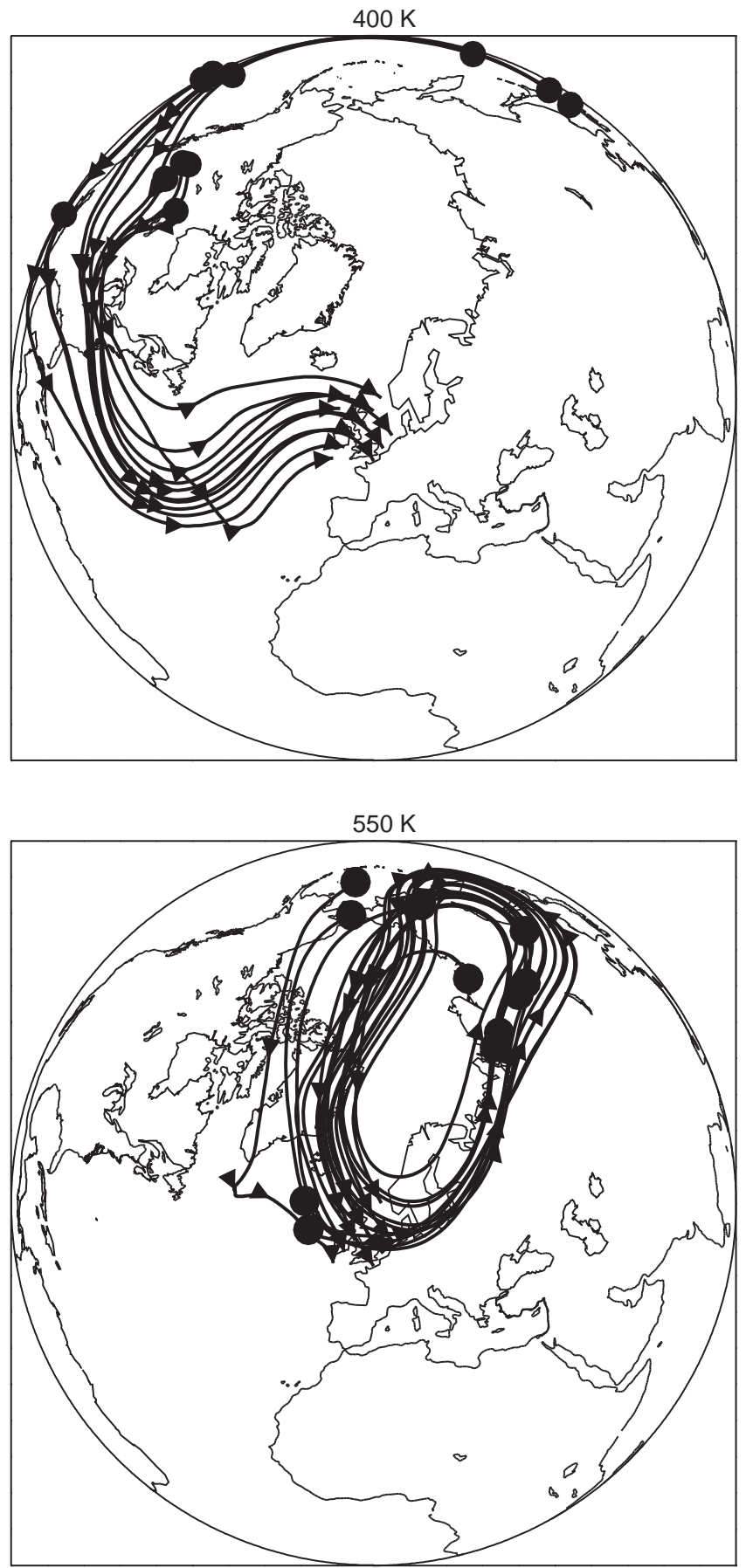

Fig. 5. 10-day air parcel trajectories calculated from analysed winds and ending on 30/4/97. Trajectories were calculated for end points at intervals of $2^{\circ}$ latitude and $2.5^{\circ}$ longitude but for clarity only every fourth trajectory is shown. The start points are indicated by the circles; the arrow heads denote the direction of travel and are plotted at

air parcels which remained near the edge of the vortex, as indicated in Fig. 5, would likely have experienced some chemical ozone loss during the spring. This loss would have been enhanced by the elongation of the vortex which allowed air parcels to be advected to lower latitudes where increased photolysis rates enhance the ozone depletion rate. Therefore the vertical ozone profiles for Lerwick together with the trajectory results
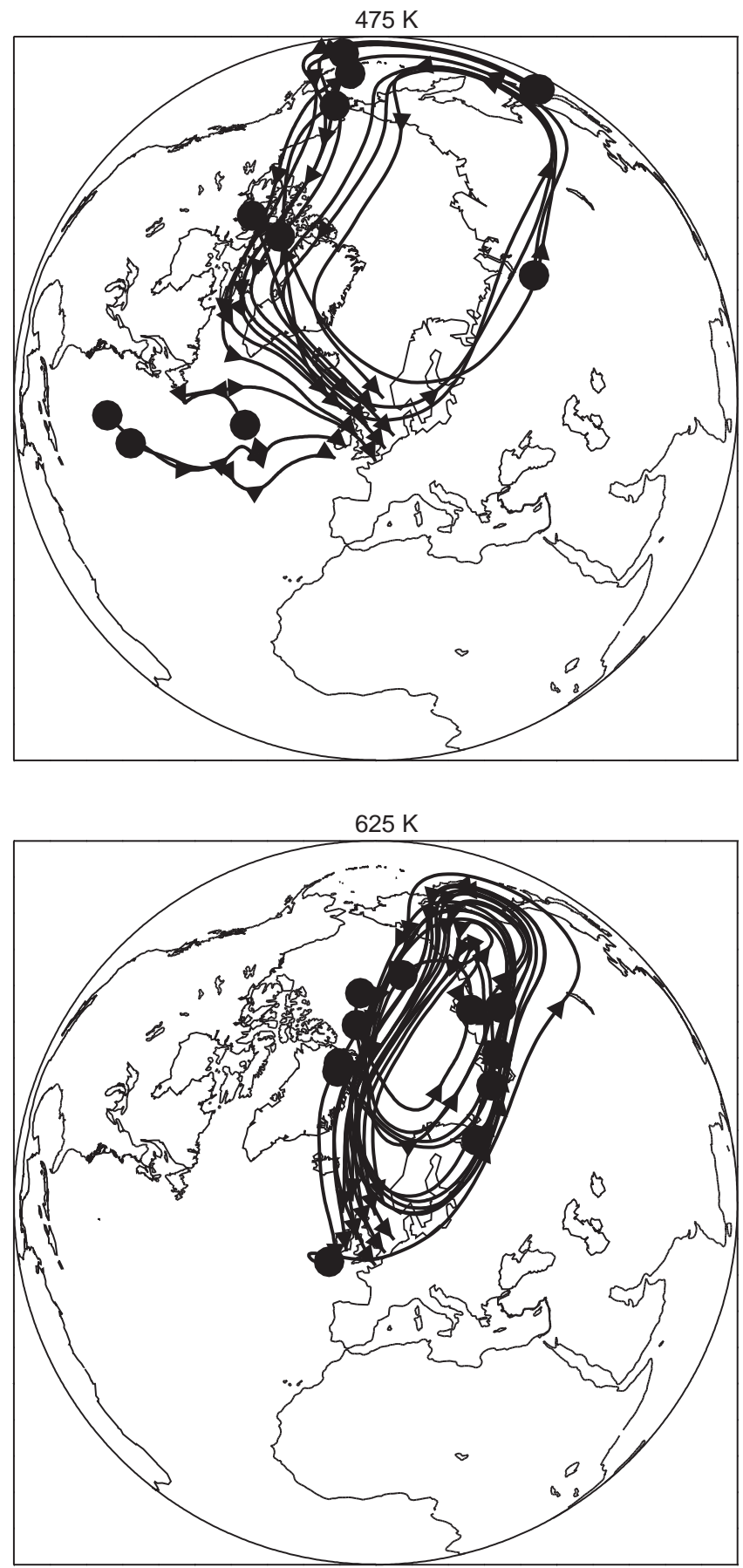

intervals of 2.5 days along each trajectory, with arrow heads also at the end points, coinciding with positions over the UK The calculations are for the potential temperature surface $\theta=400 \mathrm{~K}, 475 \mathrm{~K}, 550 \mathrm{~K}$ and $625 \mathrm{~K}$

suggest that just over half the ozone loss relative to recent climatology occurred due to meteorological effects because of the surface anticyclonic conditions and transport from the subtropics. The remainder was probably due to the presence of ozone-depleted air inside and on the edge of the polar vortex. This chemical depletion would have occurred a month or more earlier when PSCs were present and would have remained 

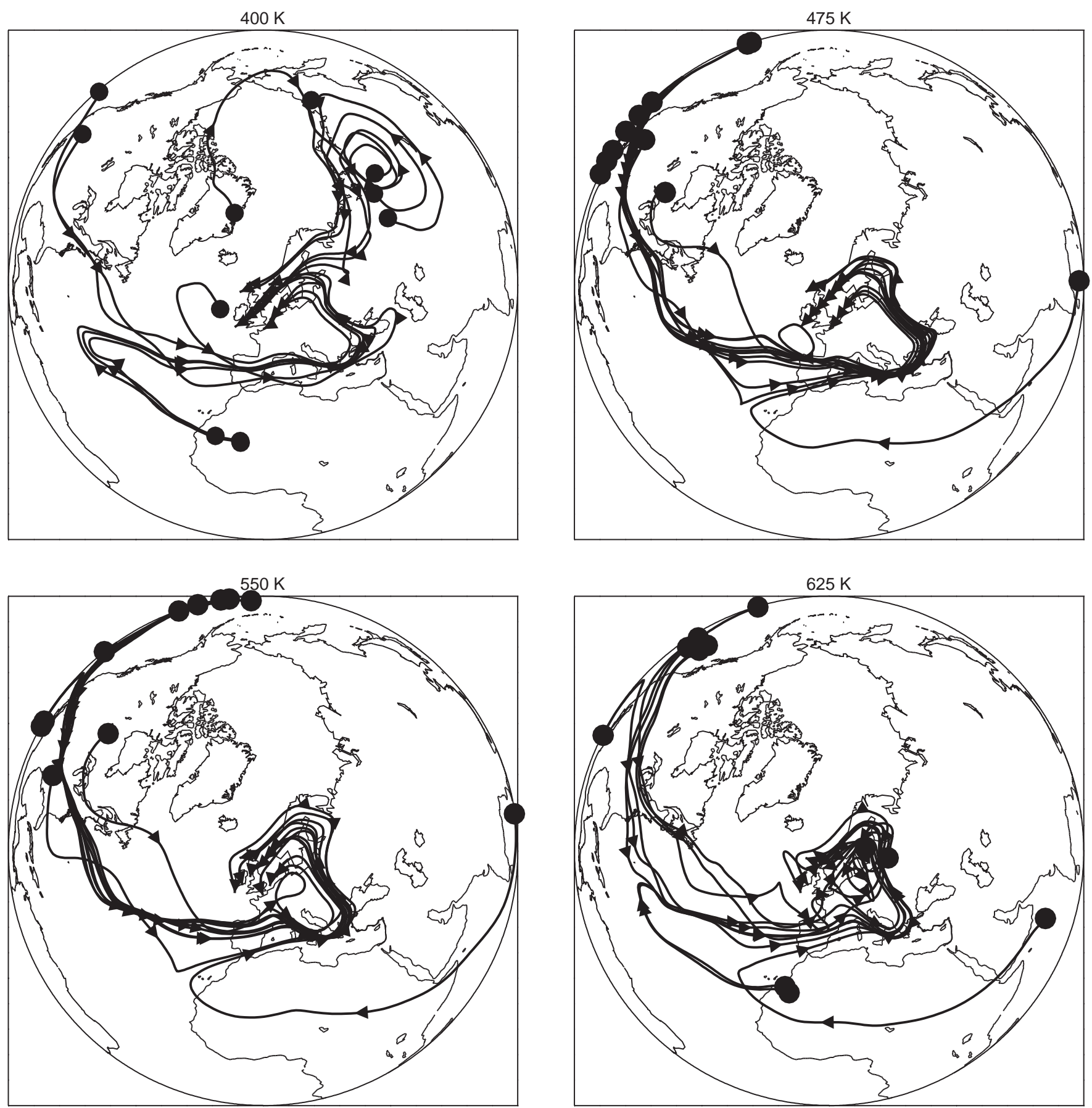

Fig. 6. As Fig. 5 but for trajectories ending on 2 May, 1998

because of the isolated nature of the polar vortex. Examination of total ozone maps based on TOVS satellite data (Neuendorffer, 1996) for February to April 1997 shows a well-defined region of low ozone in the polar vortex early in the period followed by transport of low ozone from the subtropics during several episodes later in the period. This is consistent with chemical depletion early in the period due to the very low temperatures (Fig. 4) followed by reversible changes associated with dynamics such as during the anticyclonic period mentioned here. Therefore this study provides an extension of previous results (Kerr and McElroy, 1993)

which have shown the effect of surface anticyclones on ultraviolet during summer conditions. Furthermore, the potential for particularly extreme events in late spring, is demonstrated.

In comparison, for a similar period in 1998, total ozone was considerably higher with most of the low level air parcels remaining in middle latitudes. Also, with fewer PSCs than in most recent years, the amount of chemical ozone depletion was considerably reduced. Preliminary estimates (European Ozone Research Coordinating Unit, 1998) confirm that chemical ozone depletion was lower in 1998 than in recent years, but still 
suggests that the column ozone would have been 15 $20 \%$ higher in the absence of chemical depletion.

\subsection{Future prospects of high $U V_{\text {ery }}$}

As noted by other authors (e.g. Austin et al., 1992; Shindell et al., 1998; WMO, 1999, Ch 12) as greenhouse gas concentrations increase further in the atmosphere, lower stratospheric temperatures will fall further. Temperatures in the high-latitude lower stratosphere in the 1990s have been lower than previous decades (WMO, 1999, Ch 5, and references therein) while the strengthening of the Arctic vortex since 1979 has also been documented (Labitzke and van Loon, 1995; Zurek et al., 1996). Also, although chlorofluorocarbons appear to have maximised in the troposphere (Montzka et al., 1993), the delay for their transport to the upper atmosphere implies that stratospheric chlorine levels are only now expected to peak while bromine amounts are likely to rise for several more years (SORG, 1996; WMO, 1999, Ch 11). Thus, further increases in peak springtime $\mathrm{UV}_{\text {ery }}$ might be expected to occur for the next decade or more.

\subsection{Impact of $U V_{\text {ery }}$ levels on human health}

To express the measured $\mathrm{UV}_{\text {ery }}$ values in biological terms, for a Sun-sensitive person, a minimal erythemal dose is about $200 \mathrm{Jm}^{-2}$. Therefore a minimal erythema (just noticeable increase in skin colouring) would have been attained in $20 \mathrm{~min}$ on 30 April, 1997, and $22 \mathrm{~min}$ on 1 May, 1997, at Camborne, compared with an expected $31 \mathrm{~min}$. While there is not a demonstrated link between erythema (sunburn) and skin cancer, a history of repeated sunburns is a strong risk factor for all types of skin cancer (Armstrong, 1993). Therefore a 30\% reduction in sunburn time could be serious if repeated frequently, although for a single high $\mathrm{UV}_{\text {ery }}$ exposure, apart from some temporary discomfort, there may be little long-term health consequence.

\section{Conclusion}

Extremely low ozone levels were observed on 30 April, 1997, over Camborne and Lerwick, due to transport from the tropics below $18 \mathrm{~km}$ where ozone is low in concentration, and transport from the Arctic vortex above $18 \mathrm{~km}$ where ozone had probably been partially depleted by chemistry. Further, during 1997 the final warming was also delayed so that any ozone depletion which had occurred during the winter was maintained in the stratospheric polar vortex. Radiation model calculations and measurements of UVA confirm that the low ozone resulted in the high $\mathrm{UV}_{\text {ery }}$ measured in spring 1997. In contrast, during the $1997 / 98$ winter any ozone depletion early in the period was offset by the transport of large amounts of ozone to high latitudes by a minor stratospheric warming and subsequently temperatures were too high for significant ozone destruction to occur in spring. The large differences between 1997 and 1998 illustrate the importance of interannual variability and the difficulty in detecting long term change in the Northern Hemisphere. In particular it would be premature to conclude, on the basis of the 1998 measurements, that the ozone layer is beginning to recover.

Although the case studies presented here were specific to Southern England, a relatively small part of Europe, some 30 million people were nonetheless potentially affected. Also, it is plausible that at other times other regions in northern middle latitudes may be at risk, as has been observed in southern middle latitudes (Atkinson et al., 1989). Consequently, if the 1996/97 conditions were to occur later in the spring in accordance with current trends in the stability of the polar vortex, with 1997/98 being perhaps an exceptional winter, this could become more serious both for human health and the biosphere. Hence, continued careful monitoring of UV and the ozone layer is essential throughout the period when ozone destruction is expected to be most extreme, over the next decade and perhaps beyond.

Acknowledgements. JA was partially supported by the DETR under contract EPG 1/1/35. CD acknowledges the support of colleagues at NRPB. SF and MM were supported by the DETR under contract EPG 1/1/27. The British Atmospheric Data Centre, Rutherford Apleton Laboratory, Chilton, Oxfordshire, kindly supplied TOMS data. We would like to thank Cathy Johnson (DETR) and two anonymous referees for their helpful comments on an earlier draft of the paper.

Topical Editor F. Vial thanks M. Rummukainen and another referee for their help in evaluating this paper.

\section{References}

Armstrong, B. K., Implications of increased solar UVB for cancer incidence, in The role of the stratosphere in global change, NATO ASI Series I, Environmental change, 8, Ed. M-L. Chanin, Springer-Verlag, London Berlin Heidelberg, 517-540, 1993.

Atkinson, R. J., W. A. Matthews, P. A. Newman, and R. A. Plumb, Evidence of the mid-latitude impact of Antarctic ozone depletion, Nature, 340, 290-294, 1989.

Austin, J., and N. Butchart, The influence of climate change and the timing of stratospheric warmings on Arctic ozone depletion, J. Geophys. Res., 99, 1127-1145, 1994.

Austin, J., and A. F. Tuck, The calculation of stratospheric air parcel trajectories using satellite data, Q. J. R. Meteorol. Soc., 111, 279-307, 1985.

Austin, J., N. Butchart and K. P. Shine, Possible Arctic ozone hole in a doubled $\mathrm{CO}_{2}$ climate, Nature, 360, 221-225, 1992. (Also front cover of that Nature issue)

Braathen, G. O., M. Rummukainen, E. Kyrö, H. Gernandt, I. S. Mikkelsen, and M. Gill, Ozone trends and PSC incidence in the Arctic vortex during the 7 winters from 1988-89 to 1994-95, J. Atmos. Chem., in press, 1998.

Butchart, N., and J. Austin, On the relationship between the quasibiennial oscillation, total chlorine and the severity of the Antarctic ozone hole, Q. J. R. Meteorol. Soc., 122, 183-217, 1996.

Chipperfield, M. P., A three dimensional model comparison of PSC processing during the Arctic winters of 1991/1992 and 1992/ 1993, Annales Geophysicae, 12, 342-354, 1994.

Chipperfield, M. P., A. M. Lee, and J. A. Pyle, Model calculations of ozone depletion in the Arctic polar vortex for 1991-92 to 1994-95, Geophys. Res. Lett., 23, 559-562, 1996. 
Clough, S. A, N. S. Grahame, and A. O'Neill, Potential vorticity in the stratosphere derived using data from satellites, $Q$. J.R. Meteorol. Soc., 111, 335-358, 1985.

Coy, L., E. R. Nash, and P. A. Newman, Meteorology of the polar vortex: Spring 1997, Geophys. Res. Lett., 24, 2693-2696, 1997.

DeMore, W. B., Sander, S. P., Golden, D. M., Hampson, R. F., Kurylo, M. J., Howard, C. J., Ravishankara, A. R., Kolb, C. E. and Molina, M. J., Chemical kinetics and photochemical data for use in stratospheric modeling, Evaluation number 12, JPL 97-4, 1997.

Driscoll, C. M. H., Increased solar UVR and ozone depletion, Radiol. Protect. Bull., 180, 14-16, 1996.

European Ozone Research Coordinating Unit, The Northern Hemisphere stratosphere in the winter of 1997/98, Report prepared based on preliminary information from THESEO (Third European Stratospheric Experiment on Ozone), pp. 10, 1998.

Farman, J. C., B. G. Gardiner, and J. D. Shanklin, Large losses of total ozone in Antarctica reveal seasonal $\mathrm{ClOx} / \mathrm{NOx}$ interaction, Nature, 315, 207-210, 1985.

von der Gathen, P., M. Rex, N. R. P. Harris, D. Lucic, B. M. Knudsen, G. O. Braathen, H. De Backer, R. Fabian, H. Fast, M. Gill, E. Kyrö, I.S. Mikkelsen, M. Rummukainen, J. Stähelin, and C. Varotsas, Observational evidence for chemical ozone depletion over the Arctic in winter 1991-92, Nature, 375, 131-134, 1995.

Hanson, D., and K. Mauersberger, Laboratory studies of the nitric acid trihydrate: implications for the south polar stratosphere, Geophys. Res. Lett., 15, 855-858, 1988.

Hoskins, B. J., M. E. McIntyre, and A. W. Robertson, On the use and significance of isentropic potential vorticity maps, $Q$. J.R. Meteorol. Soc., 111, 877-946, 1985.

Kerr, J. B., and C. T. McElroy, Evidence for large upward trends of ultraviolet radiation linked to ozone depletion, Science, 262, 1032-1034, 1993.

Knudsen, B. M., and G. T. Carver, Accuracy of the isentropic trajectories calculated for the EASOE campaign, Geophys. Res. Lett., 21, 1999-1202, 1994

Labitzke, K., and H. van Loon, A note on the distribution of trends below $10 \mathrm{hPa}$ : The extratropical Northern Hemisphere, J. Meteorol. Soc. Japan, 73, 883-889, 1995.

McKinlay, A., and B. L. Diffey, A reference action spectrum for ultraviolet induced erythema in human skin, in Human Exposure to Ultraviolet Radiation: Risks and Regulations, Eds. W.F. Passchier and B.F. Bosnajakovic, Elsevier, Amsterdam, pp. 8387, 1987.

Molyneux, M. J., S. F. G. Farmer and D. M. Moore, Unusually low monthly mean total ozone over southern England during April 1997, in Polar stratospheric ozone 1997, Eds. N.R.P. Harris, I. Kilbane-Dawe and G.T. Amanatidis, European Communities, Air pollution research report 66 pp. 220-223, Luxembourg, 1998.

Montzka, S. A., J. H. Butler, R. C. Myers, T. M. Thompson, T. H. Swanson, A. D. Clarke, L. T. Lock, and J. W. Elkins, Decline in the tropospheric abundance of halogen from halocarbons: implications for stratospheric ozone depletion, Science, 272, 1318-1322, 1996.

Muller, R. et al., Severe chemical ozone loss in the Arctic during the winter of 1995-96, Nature, 389, 709-712, 1997.

Naujokat, B., and S. Pawson, The cold stratospheric winters 1994 1995 and 1995/1996, Geophys. Res. Lett., 23, 3703-3706, 1996.

Neuendorffer, A. C., Ozone monitoring with TIROS-N operational vertical sounders, J. Geophys. Res., 101, 18,807-18,828, 1996.
Ohring, G., and H. S. Muench, Relationships between ozone and meteorological parameters in the lower stratosphere, J. Meteorol., 17, 195-206, 1960.

Pawson, S. and B. Naujokat, Trends in daily wintertime temperatures in the northern stratosphere, Geophys. Res. Lett., 24, 575-578, 1997.

Randel, W. J., and F. Wu, Cooling of the Arctic and Antarctic polar atmospheres due to ozone depletion, J. Clim., in press, 1998.

Rex M., N. R. P. Harris, P. von der Gathen, R. Lehmann, G. O. Braathen, E. Reimer, A. Beck, M. P. Chipperfield, R. Alfier, M. Allaart, F. O'Connor, H. Dier, V. Dorokhov, H. Fast, M. Gil, E. Kyrö, Z. Litynska, I. S. Mikkelsen, M. G. Molyneux, H. Nakane, J. Notholt, M. Rummukainen, P. Viatte, and J. Wenger, Prolonged stratospheric ozone loss in the 1995-96 Arctic winter, Nature, 389, 835-838, 1997.

Rex, M., von der Gathen, P., N. R. P. Harris, D. Lucic, B. M. Knudsen, G. O. Braathen, S. J. Reid, H. De Backer, H. Claude, R. Fabian, H. Fast, M. Gil, E. Kyrö, I. S. Mikkelsen, M. Rummukainen, H. G. Smit, J. Stähelin, C. Varotsas, and I. Zaitcev, In situ measurements of stratospheric ozone depletion rates in the Arctic winter 1991/1992: A Lagrangian approach, J. Geophys. Res., 103, 5843-5853, 1998.

Russell, J. M. III (Ed.), Satellite observations, Middle Atmosphere Program, Handbook for MAP, 22, 302pp, 1986.

Shindell, D. T., D. Rind, and P. Lonergan, Increased polar stratospheric ozone losses and delayed eventual recovery owing to increasing greenhouse-gas concentrations, Nature, 392, 589592, 1998.

Shine, K. P., On the modelled thermal response of the Antarctic stratosphere to a depletion of ozone, Geophys. Res. Lett., 13, 1331-1334, 1986.

Solomon, S., Progress towards a quantitative understanding of Antarctic ozone depletion, Nature, 347, 347-354, 1990.

Steinbrecht, W., H. Claude, U. Köler and K. P. Hoinka, Correlations between tropopause height and total ozone: Implications for long-term changes, J. Geophys. Res., 103, 19,183-19,192, 1998.

Stolarski, R. S., Monitoring stratospheric ozone from space, in The role of the stratosphere in climate change, Ed. Chanin, M-L, NATO ASI I8, Springer-Verlag Berlin Heidelberg New York, pp. 319-346, 1993.

SORG, Stratospheric Ozone 1993, Fifth report of the United Kingdom Stratospheric Ozone Review Group, HMSO, London, 1993.

SORG, Stratospheric Ozone 1996, Sixth report of the United Kingdom Stratospheric Ozone Review Group. Department of Environment reference number 96DPL0020, 1996.

Swinbank, R., and A. O'Neill, A stratosphere-troposphere data assimilation system., Mon. Weather Rev., 122, 686-702, 1994.

UMIRG, The potential effects of ozone depletion in the United Kingdom, Report by the United Kingdom UVB Measurements and Impacts Review Group, London, The Stationary Office, 1996.

WMO, WMO guide to instruments and methods of observation, WMO Report 8, 1996.

WMO, Scientific assessment of ozone depletion: 1998, WMO Global Ozone Research and Monitoring Project, Report 44, 1999.

Zurek, R. W., G. L. Manney, A. J. Miller, M. E. Gelman, and R. M. Nagatani, Interannual variability of the north polar vortex in the lower stratosphere during the UARS mission, Geophys. Res. Lett., 23, 289-292, 1996. 